\title{
Carbohydrate of the Brown Seaweed, Saccharina latissima: A Review
}

\author{
*Saifullah and Yngvar Olsen \\ Department of Biology, Faculty of Natural Sciences \\ Norwegian University of Science and Technology
}

N-7491 Trondheim, Norway

Mr.saifullah@ntnu.no

\author{
Dini Surilayani \\ Department of Fisheries, Faculty of Agriculture \\ University of Sultan Ageng Tirtayasa \\ Jl. Raya Jakarta Km.4 Pakupatan, Serang-Banten 42118, \\ Indonesia \\ dini.surilayani@untirta.ac.id.
}

\author{
Aleksander Handå \\ SINTEF Fisheries and Aquaculture, Department of Marine Resources Technology \\ Department of Marine Resources Technology \\ N-7465 Trondheim, Norway \\ Aleksander.Handa@sintef.no
}

\begin{abstract}
Saccharina latissima is one of the potential seaweed sources because of its high carbohydrate content. The interest of farming of macroalgae has increased in European countries. Abundant research results have provided data for the biochemical composition of $S$. latissimi. This paper collects and summarize data on carbohydrate content of $S$. latissima from scientific articles published all around the world. The content of polysaccharides in $S$. latissima range from 30 to $50 \% \mathrm{dw}$. These polysaccharides include alginate, fucoidan, laminarin and mannitol. Information of the carbohydrate content of $S$. latissima will be needed for further developments, such as use in biofuel, food or health industries. It may also increase the interest of cultivation of $S$. latissima. As a result, $S$. latissima may become an important commodity in aquaculture.
\end{abstract}

\section{Keywords: Carbohydrate, Saccharina latissimi, seaweed}

\section{INTRODUCTION}

Seaweed farming mostly undertaken in Asian countries. Recently, it also conducted in some African, American and European countries. It is a relatively new industry in North America and Europe[1]. The production has grown by $119 \%$ since 1984[2], showing an increased interest of seaweed cultivation. The large increase of seaweed production from 1984 to 1994 includes chlorophytes, rhodophytes and phaeophytes, with increase value of $376 \%, 167 \%$ and $97 \%$ respectively[2]. The global production of seaweed in 2016 dominated by Euchema spp, Laminaria japonica, Gracilaria spp., Undaria pinnatifida, Kappaphycus alvarezii, and Porphyra spp. [3].

Seaweed are cultivated both as a raw material for seaweed industries and for human food. Seaweed biomass has a potential as a source for producing biofuels [4]; nutraceuticals or functional food [5, 6]; pharmaceutical or medical [7-9] and food [2, 10-12]. The utilization of seaweed has also increased for environmental purpose. Studies on macroalgae farming close to fish farms have revealed that seaweed has the potential for bioremediation services [13,14].

The high use of seaweed inseparable from its nutritional content, which may up to $50 \%$ for the carbohydrate content [15]. Beside direct consumption, seaweed are also extracted for agars, carrageenans and alginates content. Gracilaria and Gelidium are the principal source of agar[16, 17], Kappaphycus and Eucheuma are the main sources of carrageenans [18], while brown seaweed (class Phaeophyceae and orders Laminariales and Fucales) have large contents of alginate (up to 55\% dw) [19]. Alaria esculenta and Saccharina latissima are the potential brown seaweed species most suited for cultivation in Europe $[13,20]$ because they hold valuable nutritional content [21]. The objective of this paper is to provide detailed information on the carbohydrate composition of S. latissima. We believe that the information provided here will give the advantages for the industrial uses of this and other macroalgae.

\section{CARBOHYDRATE OF Saccharina latissima}

Total carbohydrate of S. latissima range from 30 to $50 \%$ $\mathrm{dw}[22]$. The most abundant carbohydrate in sugar kelp ( $S$. latissima) is alginate that constitutes up to $40 \%$ [23]. Handå et $a l$. found that the alginate content of sugar kelp was in the range between 6 and 27\%[13]. Alginate content of Laminaria saccharina from Barents Sea were found to be $34.5 \pm 1.00 \%$ $\mathrm{dw}[24]$, and Shiener et al. notified an average alginate content of $28.5 \pm 3.9 \%$ of the dry weight for S. latissima from Scottish waters [25]. Alginic acid distributed universally among the Phaeophyta [26]. Jard et al. suggested that S. latissima is the best algae suited for alginate extraction[27]. It is also a key species for the food industries, and S. latissima is therefore a main candidate for seaweed aquaculture. Total alginate of $S$. latissima is lower than that of Himanthalia elongata (Table 1), but the thickening properties of alginate from S. latissima is better than that of other brown algae mentioned [27]. 
TABLE I

Total Alginate of The SELECTEd BRown SEAWEED*

\begin{tabular}{|l|l|l|l|l|l|}
\hline \multicolumn{5}{|c|}{ Brown seaweed species } & \\
\hline $\begin{array}{l}\text { Total } \\
\text { alginate } \\
(\mathrm{x} 1.18\end{array}$ & $\begin{array}{l}\text { Undaria. } \\
\text { pinnatifida } \\
\text { uronic } \\
\text { acid) } \\
\text { (g/kg } \\
\text { TS) }\end{array}$ & $\begin{array}{l}\text { Saccor } \\
\text { hiza. } \\
\text { polysc } \\
\text { hides }\end{array}$ & $\begin{array}{l}\text { Sargassu } \\
\text { m. } \\
\text { muticum }\end{array}$ & $\begin{array}{l}\text { Sacchari } \\
\text { na. } \\
\text { latissima }\end{array}$ & $\begin{array}{l}\text { Himanth } \\
\text { alia. } \\
\text { elongata }\end{array}$ \\
\cline { 2 - 6 } & 222 & 192 & 160 & 243 & 350 \\
& & & & & \\
\hline *27] & & & & & \\
\hline
\end{tabular}

**total alginate contents were obtained from corresponding references.

Subsequent to alginate, laminaran comprise up to $35 \%$ $\mathrm{dw}$ of brown seaweed [15, 28]. Laminaran, together with fucoidan, are primarily found in species of Laminaria and Fucus [26]. Laminaran from S. latissima was found around $3 \%-9 \%$ in the vicinity of salmon farm in Norway [13]. The content of laminaran from the fronds of $L$. saccharina at sheltered area has been found to be below $26 \% \mathrm{dw}$ [29]. Studies on the laminaran content of $L$. saccharina from Barents Sea showed that the content of Laminaran were $11.6 \pm 2.65 \% \mathrm{dw}$ [24]. Comparison of laminaran content of $S$. latissima by Black (1950) suggested that laminaran was higher in plants grown in the sheltered zone than in more exposed plants [29].

Another commercial carbohydrate of brown seaweed is fucoidan, which may present contents up to $15 \%$ of $\mathrm{dw}$ [30]. The maximum and minimum fucoidan value of $6.2 \pm 0.06$ and $2.3 \pm 0.04 \%$ of DM, respectively, was observed in S. latissima grown in Danish waters [31]. The highest contents of fucoidan has been found in $L$. saccharina from the Barents Sea, with fucoidan contents of $8.8 \pm 0.9 \% \mathrm{dw}$ [24].

L. saccharina also contains up to $14 \%$ of the polysaccharide mannitol [30]. Other study publish mannitol values of $15.04 \pm 2.03 \% \mathrm{dw}$ were found in L. saccharina grown in the Barent Sea [24]. Values from the Island of Frøya in Norway has shown mannitol content of 2.05\%-15.84\% DM [32]. The average mannitol content S. latissima from Scottish waters of $18.6 \pm 4.7 \%$ are reported was [25]. The higher mannitol on $L$. saccharina are underneath $24 \%$ dw reported from British Laminariaceae [29]

\section{POTENCY Of COMMERCiAl PRODUCTION OF SEAWEED BIOMASS}

The worldwide aquaculture production of aquatic plant dominated by macroalgae showed production yields above 30 million tonnes in 2016 [3]. The average world yield of macroalgae is higher than those of wheat, maize, sugar beet and sugar cane [33]. This makes seaweed available as an industrial raw material for commercial product, and it is suggested that marine sources has the largest biomass potential compare to other sources [34]. In addition to that, huge biomass required for the industrialization of seaweed may reach through aquaculture.

$S$. latissima, as a potential species for seaweed aquaculture, is one of the fastest growing species of kelp in European waters [35, 36], and the species show good growth performance [37]. In Norway, the procedure for seedling production of $S$. latissima has been established through research activities [36], and further farming activities is initiated. Through the MACROSEA project (https://www.sintef.no/projectweb/macrosea/), we will also contribute to provide a knowledge platform for industrial macroalgae cultivation.

\section{CONCLUSION}

S. latissima has a relatively high content of total carbohydrates. The carbohydrate includes of alginate, fucoidan, laminarin and mannitol, components that can be used for production of biofuel, food and health products. Protocol for the aquaculture of S. latissima has also established in Norway.

\section{ACKNOWLEDGMENT}

The work was a part of the Research Council of Norway project no.254883/E40 (MACROSEA) and funding from the Department of Biology, Norwegian University of Science and Technology.

\section{REFERENCES}

[1] J. K. Kim, C. Yarish, E. K. Hwang, M. Park, and Y. Kim, "Seaweed aquaculture: cultivation technologies, challenges and its ecosystem services," Algae, vol. 32, no. 1, pp. 1-13, 2017.

[2] W. Lindsey Zemke-White, and M. Ohno, "World seaweed utilisation: An end-of-century summary," Journal of Applied Phycology, vol. 11, no. 4 , pp. $369-376,1999$.

[3] FAO, The state of world fisheries and aquaculture 2018 - Meeting the sustainable development goals., Rome: Food and Agriculture Org. of the United Nations, 2018.

[4] N. Wei, J. Quarterman, and Y. S. Jin, "Marine macroalgae: an untapped resource for producing fuels and chemicals," Trends Biotechnol, vol. 31, no. 2, pp. 70-7, Feb, 2013.

[5] M. L. Wells, P. Potin, J. S. Craigie, J. A. Raven, S. S. Merchant, K. E. Helliwell, A. G. Smith, M. E. Camire, and S. H. Brawley, "Algae as nutritional and functional food sources: revisiting our understanding," J Appl Phycol, vol. 29, no. 2, pp. 949-982, 2017.

[6] A. Jiménez-Escrig, E. Gómez-Ordóñez, and P. Rupérez, "Brown and red seaweeds as potential sources of antioxidant nutraceuticals," Journal of Applied Phycology, vol. 24, no. 5, pp. 1123-1132, 2012/10/01, 2012.

[7] Q. Shi, A. Wang, Z. Lu, C. Qin, J. Hu, and J. Yin, "Overview on the antiviral activities and mechanisms of marine polysaccharides from seaweeds," Carbohydrate Research, vol. 453-454, pp. 1-9, 2017/12/01/, 2017.

[8] S. L. Holdt, and S. Kraan, "Bioactive compounds in seaweed: functional food applications and legislation," Journal of Applied Phycology, vol. 23, no. 3, pp. 543-597, 2011. 
[9] M. Falkenberg, E. Nakano, L. Zambotti-Villela, G. A. Zatelli, A. C. Philippus, K. B. Imamura, A. M. A. Velasquez, R. P. Freitas, L. de Freitas Tallarico, P. Colepicolo, and M. A. S. Graminha, "Bioactive compounds against neglected diseases isolated from macroalgae: a review," Journal of Applied Phycology, 2018/09/11, 2018.

[10] J. Fleurence, M. Morançais, J. Dumay, P. Decottignies, V. Turpin, M. Munier, N. Garcia-Bueno, and P. Jaouen, "What are the prospects for using seaweed in human nutrition and for marine animals raised through aquaculture?," Trends in Food Science \& Technology, vol. 27, no. 1, pp. 57-61, 2012.

[11] T. Fujiwara-Arasaki, N. Mino, and M. Kuroda, "The protein value in human nutrition of edible marine algae in Japan," The International Journal of Aquatic Sciences, vol. 116, no. 1, pp. 513-516, 1984.

[12] K. Nisizawa, H. Noda, R. Kikuchi, and T. Watanabe, "The main seaweed foods in Japan," The International Journal of Aquatic Sciences, vol. 151, no. 1, pp. 5-29, 1987.

[13] A. Handå, S. Forbord, X. Wang, O. J. Broch, S. W. Dahle, T. R. Størseth, K. I. Reitan, Y. Olsen, and J. Skjermo, "Seasonal- and depthdependent growth of cultivated kelp (Saccharina latissima) in close proximity to salmon (Salmo salar) aquaculture in Norway," Aquaculture, vol. 414-415, pp. 191-201, 2013.

[14] T. Chopin, A. H. Buschmann, C. Halling, M. Troell, N. Kautsky, A. Neori, G. P. Kraemer, J. A. Zertuche-González, C. Yarish, and C. Neefus, "Integrating Seaweeds Into Marine Aquaculture Systems: A Key Toward Sustainability," 2001, pp. 975-986.

[15] M. T. Cesário, M. M. R. da Fonseca, M. M. Marques, and M. C. M. D. de Almeida, "Marine algal carbohydrates as carbon sources for the production of biochemicals and biomaterials," Biotechnology Advances, vol. 36, no. 3, pp. 798-817, 2018.

[16] C. Madhusudan, S. Manoj, K. Rahul, and C. M. Rishi, "Seaweeds: A diet with nutritional, Medicinal and Industrial value," Research Journal of Medicinal Plant, vol. 5, no. 2, pp. 153-157, 2011.

[17] H. J. Bixler, and H. Porse, "A decade of change in the seaweed hydrocolloids industry," Journal of Applied Phycology, vol. 23, no. 3, pp. 321-335, 2010 .

[18] E. I. Ask, and R. V. Azanza, "Advances in cultivation technology of commercial eucheumatoid species: a review with suggestions for future research," Aquaculture, vol. 206, no. 3, pp. 257-277, 2002/04/22/, 2002.

[19] C. Peteiro, "Alginate Production from Marine Macroalgae, with Emphasis on Kelp Farming," Alginates and Their Biomedical Applications, Springer Series in Biomaterials Science and Engineering. B. H. A. Rehm and M. F. Moradali, eds., pp. 27-66, Singapore: Springer, 2018

[20] S. Kraan, A. Verges Tramullas, and M. Guiry, "The edible brown seaweed Alaria esculenta (Phaeophyceae, Laminariales): hybridization, growth and genetic comparisons of six Irish populations," Journal of Applied Phycology, vol. 12, no. 6, pp. 577-583, 2000.

[21] P. Stévant, H. Marfaing, T. Rustad, I. Sandbakken, J. Fleurence, and A. Chapman, "Nutritional value of the kelps Alaria esculenta and Saccharina latissima and effects of short-term storage on biomass quality," Journal of Applied Phycology, vol. 29, no. 5, pp. 2417-2426, 2017/10/01, 2017

[22] A. Jensen, "Present and future needs for algae and algal products," Hydrobiologia, vol. 260/261, pp. 15-23, 1993.

[23] K. I. Draget, O. Smidsrød, and G. Skjåk-Bræk, "Alginates from algae," Biopolymers online, A. Steinbüchel, ed.: Wiley-VCH Verlag GmbH \& Co. KGaA, 2005.

[24] E. Obluchinskaya, "Comparative chemical composition of the Barents Sea brown algae," Applied Biochemistry and Microbiology, vol. 44, no. 3, pp. 305-309, 2008

[25] P. Schiener, K. D. Black, M. S. Stanley, and D. H. Green, "The seasonal variation in the chemical composition of the kelp species Laminaria digitata, Laminaria hyperborea, Saccharina latissima and Alaria esculenta," Journal of Applied Phycology, vol. 27, no. 1, pp. 363-373, 2014.

[26] H. G. Mautner, "The chemistry of brown algae," Economic Botany, vol 8, no. 2, pp. 174-192, 1954/04/01, 1954.
27] G. Jard, H. Marfaing, H. Carrère, J. P. Delgenes, J. P. Steyer, and C. Dumas, "French Brittany macroalgae screening: Composition and methane potential for potential alternative sources of energy and products," Bioresource Technology, vol. 144, pp. 492-498, 2013/09/01/, 2013

[28] S. M. Cardoso, L. G. Carvalho, P. J. Silva, M. S. Rodrigues, O. R Pereira, and L. Pereira, "Bioproducts from Seaweeds: A Review with Special Focus on the Iberian Peninsula," Current Organic Chemistry, vol. 18, no. 7, pp. 896-917, //, 2014.

[29] W. A. P. Black, "The seasonal variation in weight and chemical composition of the common British Laminariaceae," Journal of the Marine Biological Association of the United Kingdom, vol. 29, no. 1, pp. 45-72, 1950.

[30] P. MacArtain, C. I. Gill, M. Brooks, R. Campbell, and I. R. Rowland, "Nutritional value of edible seaweeds," Nutr Rev, vol. 65, no. 12 Pt 1, pp. 535-43, Dec, 2007.

[31] A. Bruhn, T. Janicek, D. Manns, M. M. Nielsen, T. J. S. Balsby, A. S. Meyer, M. B. Rasmussen, X. Hou, B. Saake, C. Göke, and A. B. Bjerre, "Crude fucoidan content in two North Atlantic kelp species, Saccharina latissima and Laminaria digitata - seasonal variation and impact of environmental factors," Journal of Applied Phycology, vol. 29, no. 6, pp. 3121-3137, 2017/12/01, 2017.

[32] S. Sharma, L. Neves, J. Funderud, L. T. Mydland, M. Øverland, and S. J. Horn, "Seasonal and depth variations in the chemical composition of cultivated Saccharina latissima," Algal Research, vol. 32, pp. 107-112, 2018.

[33] J. M. Adams, J. A. Gallagher, and I. S. Donnison, "Fermentation study on Saccharina latissima for bioethanol production considering variable pre-treatments," Journal of Applied Phycology, vol. 21, no. 5, pp. 569$574,2008$.

[34] E. de Jong, and G. Jungmeier, "Chapter 1 - Biorefinery Concepts in Comparison to Petrochemical Refineries," Industrial Biorefineries \& White Biotechnology, A. Pandey, R. Höfer, M. Taherzadeh, K. M. Nampoothiri and C. Larroche, eds., pp. 3-33, Amsterdam: Elsevier, 2015.

[35] J. C. Sanderson, M. J. Dring, K. Davidson, and M. S. Kelly, "Culture, yield and bioremediation potential of Palmaria palmata (Linnaeus) Weber \& Mohr and Saccharina latissima (Linnaeus) C.E. Lane, C. Mayes, Druehl \& G.W. Saunders adjacent to fish farm cages in northwest Scotland," Aquaculture, vol. 354-355, no. C, pp. 128-135, 2012.

[36] S. Forbord, J. Skjermo, J. Arff, A. Handå, K. I. Reitan, R. Bjerregaard, and K. Lüning, "Development of Saccharina latissima (Phaeophyceae) kelp hatcheries with year-round production of zoospores and juvenile sporophytes on culture ropes for kelp aquaculture," Journal of Applied Phycology, vol. 24, no. 3, pp. 393-399, 2012.

[37] I. C. Azevedo, G. S. Marinho, D. M. Silva, and I. Sousa-Pinto, "Pilot scale land-based cultivation of Saccharina latissima Linnaeus at southern European climate conditions: Growth and nutrient uptake at high temperatures," Aquaculture, vol. 459, pp. 166-172, 2016. 